\title{
3. NEOGENE-QUATERNARY DEPOSITIONAL HISTORY OF THE EAST GREENLAND SHELF IN THE VICINITY OF LEG 152 SHELF SITES ${ }^{1}$
}

\author{
Holger Lykke-Andersen ${ }^{2}$
}

\begin{abstract}
The seismic stratigraphic architecture of the late Neogene-Quaternary deposits on the shelf in the vicinity of Sites 914-917 is described on the basis of high-resolution reflection seismic data. The geological history of the shelf is discussed. During the late Cenozoic, a huge progradational wedge was built as a consequence of enhanced erosion due to the evolving glaciation. It is inferred that the wedge is composed mainly of glaciomarine diamictons deposited outside the grounding line at the paleo-shelf edge. The sediments and the glaciers were supplied to the shelf through the Gyldenløves Trough cut into the basement on the inner shelf. By repeated glaciations, erosion was maintained in the prolongation of Gyldenløves Trough. This erosional trough was partially filled by proglacial deposits during recession periods and possibly by subglacial deposits in periods of glacial advances. It is thought that the infill process was initiated because of relative sea level rise in the Quaternary or possibly in the Pliocene. The infilling continued in the Quaternary. A surficial transparent sheet on the outer shelf is interpreted as basal till deposited by ice covering the whole shelf in the Quaternary. The youngest till on the outer shelf is interpreted to be of Saalian age; Weichselian glaciations apparently are only represented by till deposits confined to the Gyldenløves Trough.
\end{abstract}

\section{INTRODUCTION}

Ocean Drilling Program (ODP) Leg 152 Sites 914-917 are located on the outer shelf in the axial region of an overdeepened trough, Gyldenløves Trough. The topography of this trough was described by Sommerhoff (1979). About $750 \mathrm{~km}$, high-resolution seismic profiles cover the outer part of Gyldenløves Trough (Fig. 1), and served as site survey data together with already existing seismic profiles with deep penetration (Larsen, Saunders, Clift, et al., 1994). These profiles, in conjunction with the results obtained from Sites 914-917, form the basis for the present study of the late Neogene and Quaternary geology of the shelf.

The high-resolution data were acquired with an acoustic source consisting of a cluster of four 40 cubic inch sleeveguns. Data were recorded on an $\sim 150 \mathrm{~m}$ long streamer containing 24 channels (Larsen, Saunders, Clift, et al., 1994). By processing data, filtered stack profiles with a stackfold of $600 \%$ were obtained. The vertical resolution is estimated to be $3-5 \mathrm{~m}$, and the depth of penetration on the shelf is normally less than $1.5 \mathrm{~s}$ two-way traveltime (TWT). Pre-rift rocks and Tertiary basalts form the acoustic basement, though the latter often show internal reflections. A highly reflective seafloor produces strong multiples that could not be removed by the processing. Consequently, interpretation of seismic profiles below the first seabed multiple is normally severely hampered, causing a problem particularly on the outer shelf where the multiple is occurring within the upper half of the Neogene-Quaternary sedimentary cover.

\section{SHELF STRATIGRAPHY-AN OVERVIEW}

During Leg 152, a seismic stratigraphic framework was established in the drilling transect on the shelf (Larsen, Saunders, Clift, et al., 1994). Four seismic stratigraphic units (1-4) were defined in the sedimentary succession covering the basaltic basement (Fig. 2). The present work is concentrated on the two upper units (1 and 2). Unit 1

${ }^{1}$ Saunders, A.D., Larsen, H.C., and Wise, S.W., Jr. (Eds.), 1998. Proc. ODP, Sci. Results, 152: College Station, TX (Ocean Drilling Program).

${ }^{2}$ Department of Earth Sciences, University of Aarhus, Finlandsgade 8, DK-8200 Aarhus N., Denmark. geofhla@aau.dk was drilled at Sites 914-917. It constitutes a sequence of glaciomarine silts, sands, gravels, and diamictons of unspecified Quaternary age. The stratigraphic position of Unit 2 is not well constrained by the stratigraphic data obtained from Sites 914-917. Based on correlation with Site 918 in the Irminger Basin via the deep seismic profile GGU81-08, an age range from late Miocene to Quaternary was suggested by Larsen et al. (1994).

Correlations based on the high-resolution seismic profiles confirm this interpretation. Although there were interpretational difficulties caused by strong multiple noise, the base of Unit 2 is a well-defined downlap surface on the shelf. This surface correlates with a downlap surface in the Irminger Basin (Figs. 3, 4). At Site 918 this surface is found at about $520 \mathrm{~ms}$ TWT below seafloor reflection. By applying the TWT-depth relation given by Larsen, Saunders, Clift, et al. (1994) a depth estimate of approximately 460 meters below seafloor (mbsf) is obtained. Considering the uncertainties inherent in the TWT-depth conversion, based as it is on discrete measurements of $P$ wave velocities on unevenly distributed core samples, the calculated depth may well represent the level at about 500 mbsf, where a dramatic upward increase in sedimentation rate was found (Larsen et al., 1994). This places the downlap surface at Site 918 close to the Miocene/Pliocene boundary. However, the downlap surface does not necessarily represent a synchronous surface.

As described in detail later the oldest and most landward part of Unit 2 is characterized by a low angle, hummocky, progradational reflection pattern that is distinctly different from the parallel pattern in the underlying Unit 3, indicating a significant change in depositional conditions from Unit 3 to Unit 2. It seems likely that this change reflects the onset of increased sediment supply to the shelf due to increased erosion by expanding glaciers on the continent. At Site 918, the first substantial influx of ice-rafted debris occurred in late Miocene (around $7 \mathrm{Ma}$ ), indicating full glaciation with glaciers calving along the shores of East Greenland. A marked decrease in the $\mathrm{CaCO}_{3}$ content of the sediments at Site 918 from early late Miocene (around 9.5 Ma) was interpreted (Larsen et al., 1994) as a consequence of a relative increase in the supply of clastic detritus from the continent, induced by the climatic cooling leading to the growth of glaciers in East Greenland. Although the timing of incipient glaciation is not uniquely determined by the observed sedimentation rates in the Irminger Basin (Larsen, Saunders, Clift, et al., 1994), it seems likely that the initial progradational part of Unit 2 is associated with the in- 


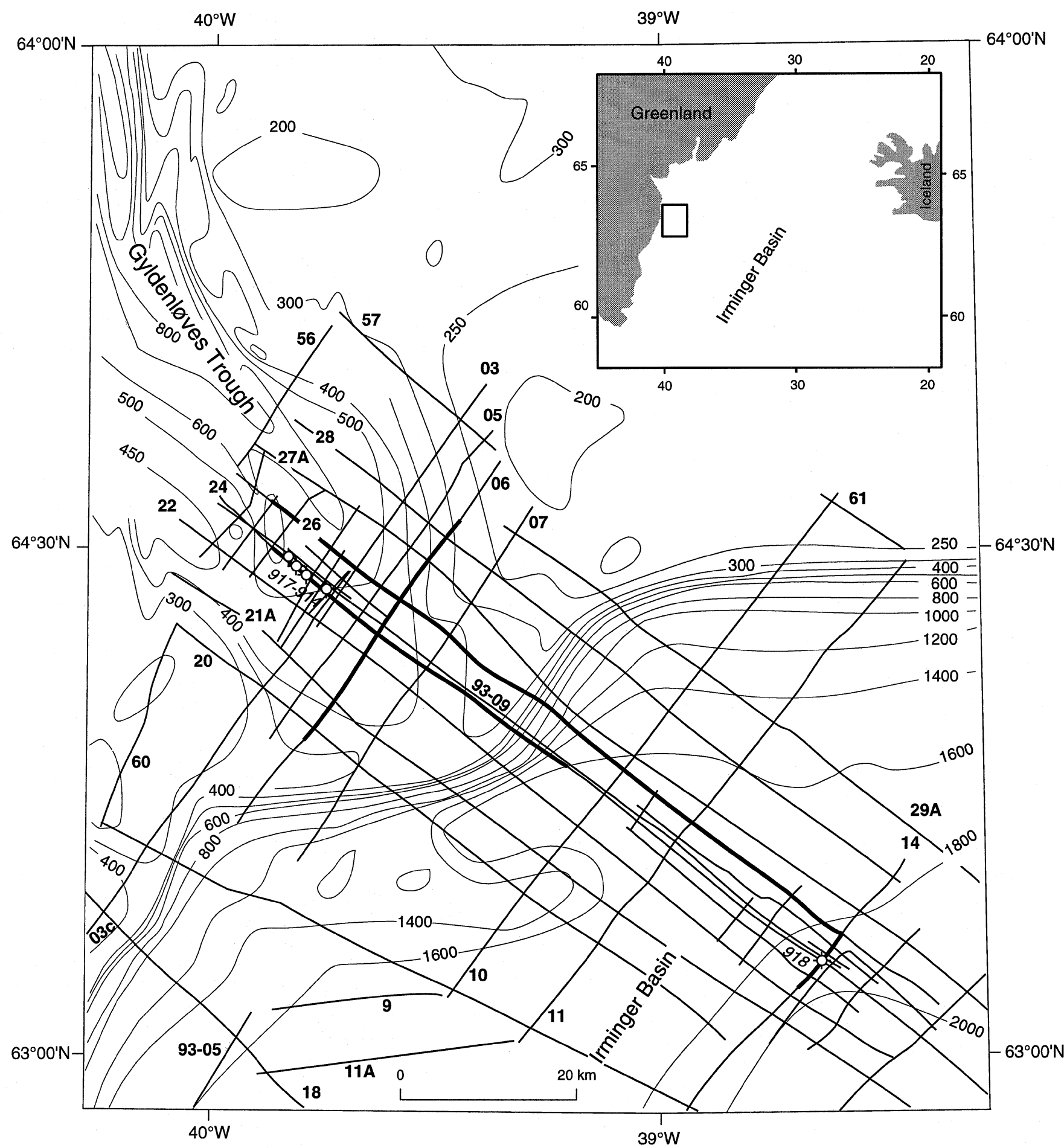

Figure 1. Bathymetric map with high-resolution seismic profiles covering the shelf and slope in the vicinity of Sites 914-918. Profiles annotated with two-digit numbers were acquired in 1992. Profiles acquired in 1993 are shown with the prefix 93.

ferred early late Miocene increase in clastic influx (see Fukuma, this volume). If this interpretation is valid, the depicted lower boundary of Unit 2 is time-transgressive in a basinward direction, and the chronostratigraphic Miocene/Pliocene boundary on the shelf is located in one of the clinoform reflections in the landward end of Unit 2.

The upper boundary of Unit 2 is very well defined on the inner shelf as a surface where the clinoforms are truncated and unconformably overlain by the flat-lying Quaternary deposits of Unit 1 . On the outer shelf, the clear erosional truncation of the clinoforms within
Unit 2 grades into a toplap relationship, and finally, near the shelf edge, the clinoform reflections can be followed into the subhorizontal reflections of Unit 1 (Figs. 2, 3). The clinoform reflection that correlates with the base of the subhorizontal reflections defines the boundary between seismic stratigraphic Units 1 and 2 in the outer part of the shelf. The boundary reflection was traced into the Irminger Basin to Site 918, and it was found that the reflection correlates approximately with the Pliocene/Quaternary boundary at about 90 mbsf (i.e., approximately $100 \mathrm{~ms}$ TWT; Wei; Fukuma; both this volume). 


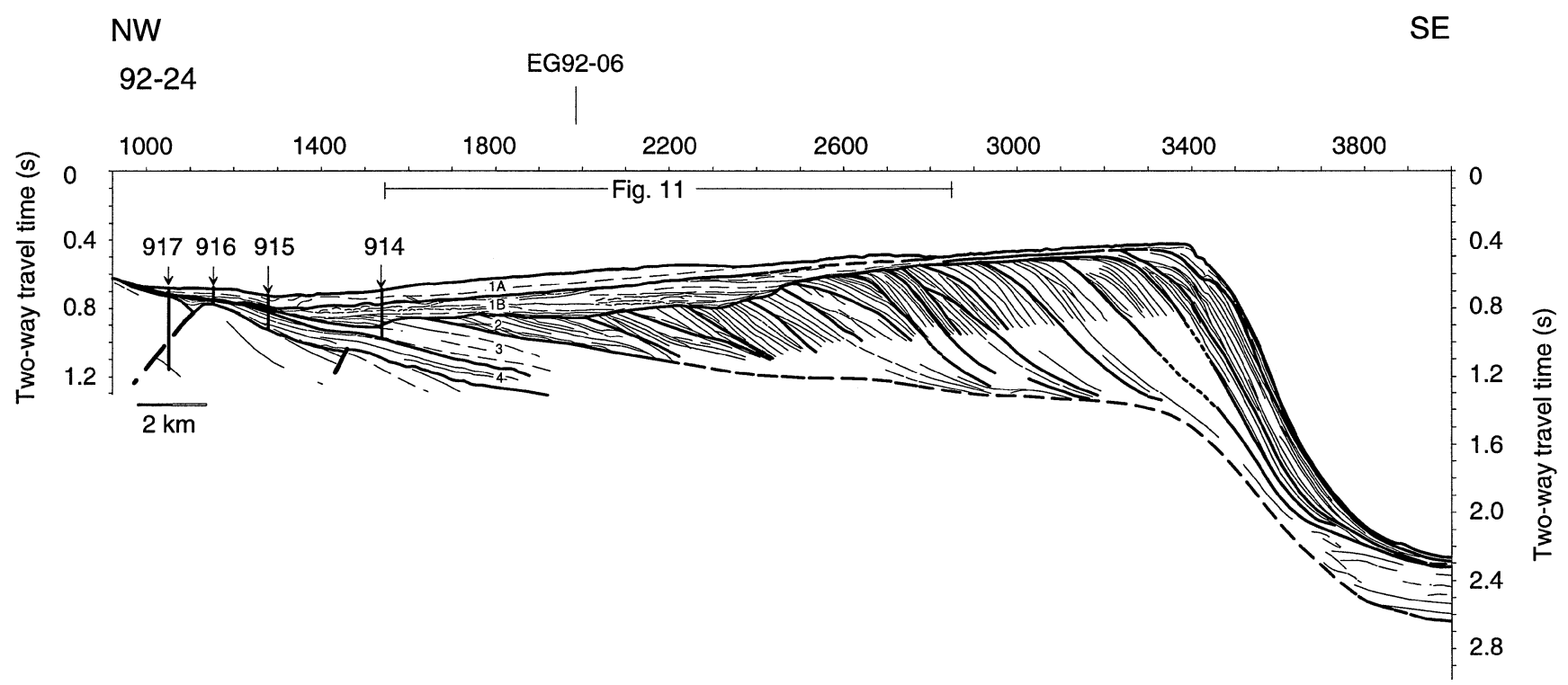

Figure 2. Seismic profile EG92-24 showing detailed seismic stratigraphic interpretation of Units 1 and 2. Boundaries between units and subunits are marked by enhanced lines. See Figure 1 for location.

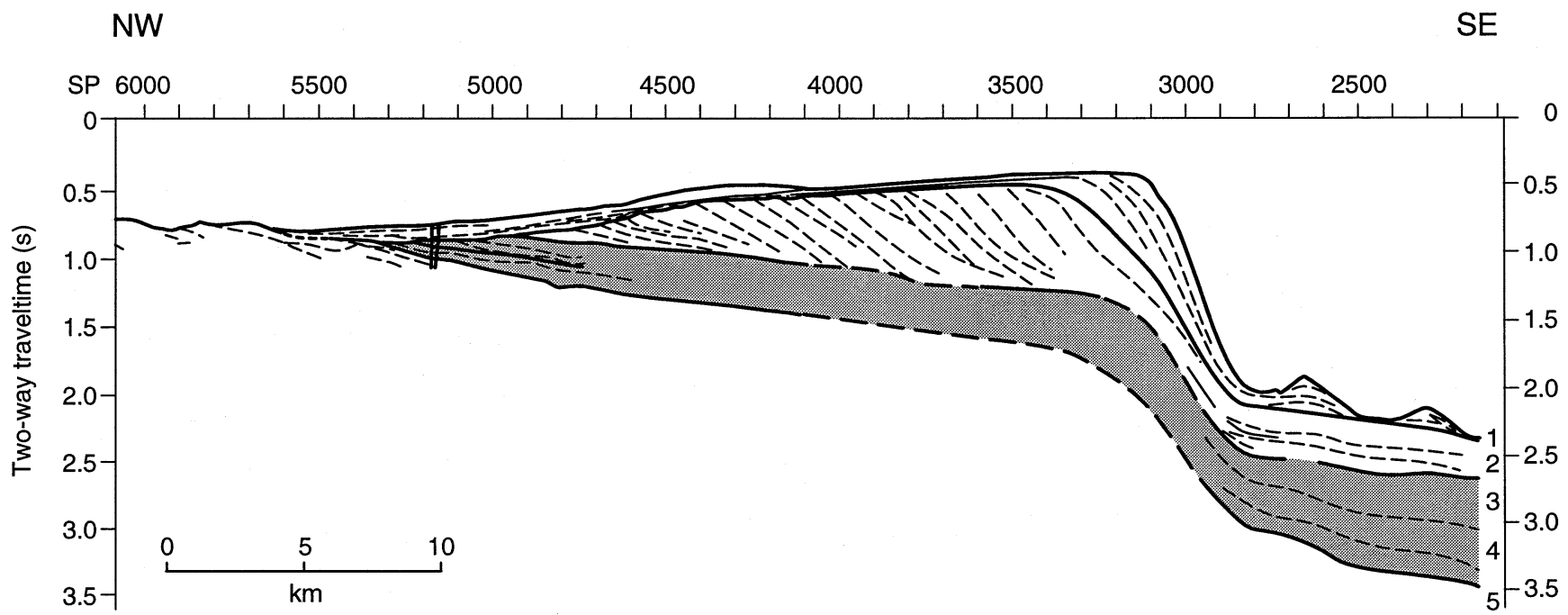

Figure 3. Northwestern part of seismic profile EG92-26 with major seismic stratigraphic units. See Figure 1 for location.

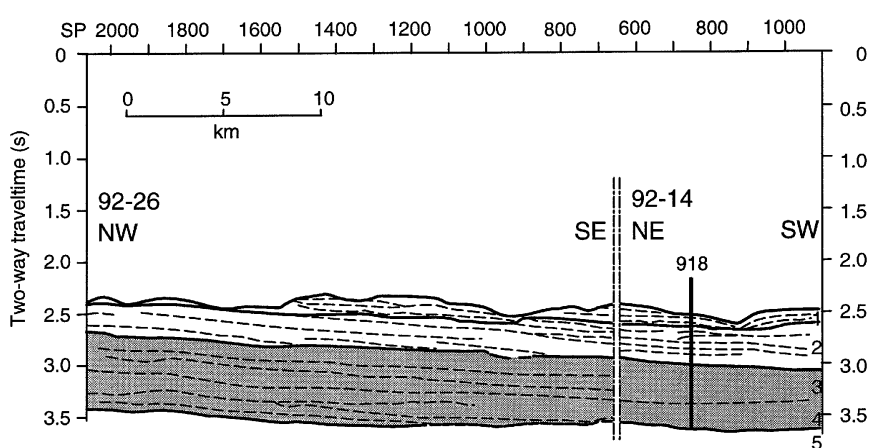

Figure 4. Southeastern part of seismic profile EG92-26 (continuation from Fig. 3) and crossing profile EG92-14 with major seismic stratigraphic units and correlations with Site 918. See Figure 1 for location.

\section{ARCHITECTURE OF UNIT 2 (LATE MIOCENE-PLIOCENE)}

The seismic stratigraphic Unit 2 is characterized by massive occurrence of prograding clinoforms. The unit can be divided into a number of subunits bounded by unconformable surfaces and distinguished by variations in internal reflection patterns. The unconformable surfaces are recognized as surfaces onto which reflections toplap or downlap and, in rare cases, as surfaces on which reflections are truncated (Fig. 2). A similar architecture is observed on the other dip profiles (EG92-20, -21A, -22, -26, -27A, -28, and EG93-09). Profiles approximately in the depositional strike direction (EG92-05, -06, and -07) show hummocky clinoform patterns in the lower parts (Fig. 5), grading into subparallel, wavy patterns in the younger subunits. Thus the three-dimensional construction of the subunits changes from a stack of relatively narrow interfingering lobes in the lower subunits to stacks of more extensive lobes and sheets in younger subunits.

Following the interpretational scheme of Mitchum et al. (1977), the first subunit might represent distal portions of a delta building out 


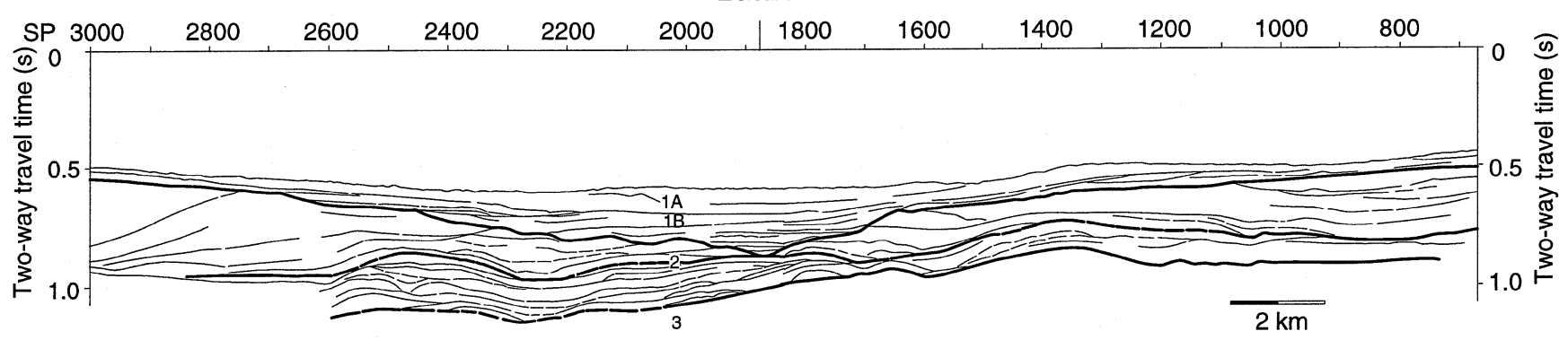

Figure 5. Seismic profile EG92-06 oriented approximately in the depositional strike direction. Hummocky clinoforms are characteristic for the lowermost part of Unit 2. See Figure 1 for location.

into relatively shallow water. The seismic profiles connecting the shelf sequence to Site 918 make it plausible that some lower portion of the progradational Unit 2 is correlated with the upper Miocene sediments containing indications of climatic cooling and initial glaciation of East Greenland. It is therefore tentatively suggested that the first subunit represents the period of incipient glaciation and that the succeeding subunits represent the following period with full glaciations.

The dip in the subunits is generally increasing in a seaward direction from about $7^{\circ}$ to about $15^{\circ}$ (Fig. 6). Depositional factors such as increase in grain size and angularity of particles may have contributed to increasing slope angle due to their effect on the permeability and friction angles of the sediments (e.g. Kenney, 1984). These factors may relate to increased glaciation and supply of detritus from the continent. The observation at Site 918 of an upward increase in the content of microscopic quartz and dropstones in the late MioceneQuaternary sequence (Larsen, Saunders, Clift, et al., 1994) supports this interpretation.

Tilting of the shelf caused by the combined effect of sediment load, glacio-isostasy and tectonics may also have influenced the observed dips. Post-rift tectonic flexuring across the shelf area caused by subsidence of the Irminger Basin has been documented (Larsen, 1980, 1990). However, tectonic tilting is not likely to have taken place during the deposition of Unit 2, and if it had, the likely effect would be an increasing enhancement of dips in direction from younger (seaward) to older (landward) parts of the unit opposite to what is seen.

The unconformities separating the subunits of Unit 2 may reflect periods of temporary reductions in sediment supply, rearrangement of depositional lobes and sheets, or a combination of these two possibilities.

The base of Unit 2 (Fig. 7) is a fairly regular surface sloping basinward $1^{\circ}-2^{\circ}$. A depression about $10 \mathrm{~km}$ wide and 100-200 m deep crosses the shelf in a northwest-southeast direction south of the drilled transect. The relatively poor data quality at this level does not allow any decision on whether the depression is a depositional or an erosional feature. Below the modern shelf slope, the base of Unit 2 forms a flexured surface with a maximum inclination of about $7^{\circ}$.

The thickness of Unit 2 is shown in Figure 8. The main, elongated depocenter, with thicknesses exceeding $800 \mathrm{~m}$, has an axis approximately concordant with the modern shelf edge. The maximum thickness (about $850 \mathrm{~m}$ ) of the main depocenter is found below the bulge in the modern shelf slope, thus showing that the bulge is a constructive feature. A secondary depocenter is located in the elongated, northwest-southeast depression in the base of the unit (cf. Fig. 7). True dips and dip directions for internal reflections at the surface of the unit were calculated at crossing seismic profiles (Fig. 8). Dip is generally increasing in a seaward direction. The dips are approximately southeast directed with a slight diverging tendency on the middle and outer shelf. Dip directions, as well as the fact that the

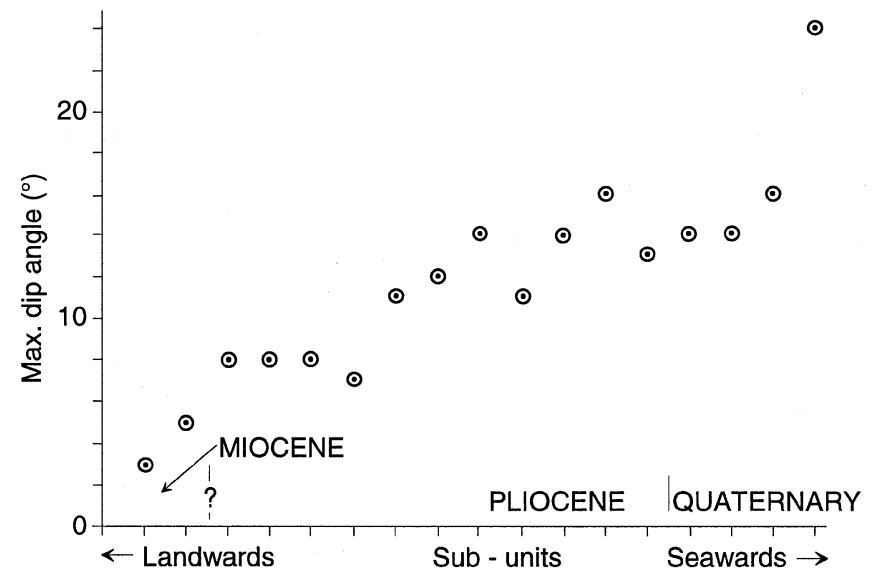

Figure 6. Apparent maximum depositional dip in subunits of Unit 2.

main depocenter is located right in front of the outlet of the deep inner-shelf part of Gyldenløves Trough (cf. Fig. 1), demonstrate that Unit 2 is formed as a trough-mouth-fan comparable to fans described at several locations along the shelves of East and West Greenland (Sommerhoff, 1979; Clausen, this volume), in the Barents Sea (Vorren et al., 1989), and in the Antarctic (Cooper et al., 1991b). The implication of this interpretation is that the ancestral Gyldenløves Trough dates back to at least Pliocene time.

\section{ARCHITECTURE OF UNIT 1 ([?PLIOCENE]-QUATERNARY)}

The seismic stratigraphic Unit 1 consists of an aggradational part extending from the inner shelf to the shelf edge and a progradational part on the continental slope (Figs. 2, 3).

The base of Unit 1 forms a wide, linear north-northwest-southsoutheast trending, up to 300-m-deep trough with its axis about $5 \mathrm{~km}$ east of the drilled transect (Fig. 9). The deepest levels in the trough are at 650-700 mbsl. Parallel to the outer shelf edge at the seaward end of the trough a $200-300 \mathrm{~m}$ high sill is located. The crest of the sill forms a pass at the paleo-shelf edge in front of the trough. Presentday bathymetry mimics all these features.

The aggradational part of Unit 1 is made up of two major subunits (1A and $1 \mathrm{~B}$ ) with distinctly different reflection patterns and mode of occurrence. The older subunit (1B) is composed of three segments: onlapping trough fill on the inner shelf, sheet drape on the outer shelf, and (seaward of that) slope front-fill (Fig. 2). The younger subunit (1A) is restricted to the trough and its nearest surroundings and is 


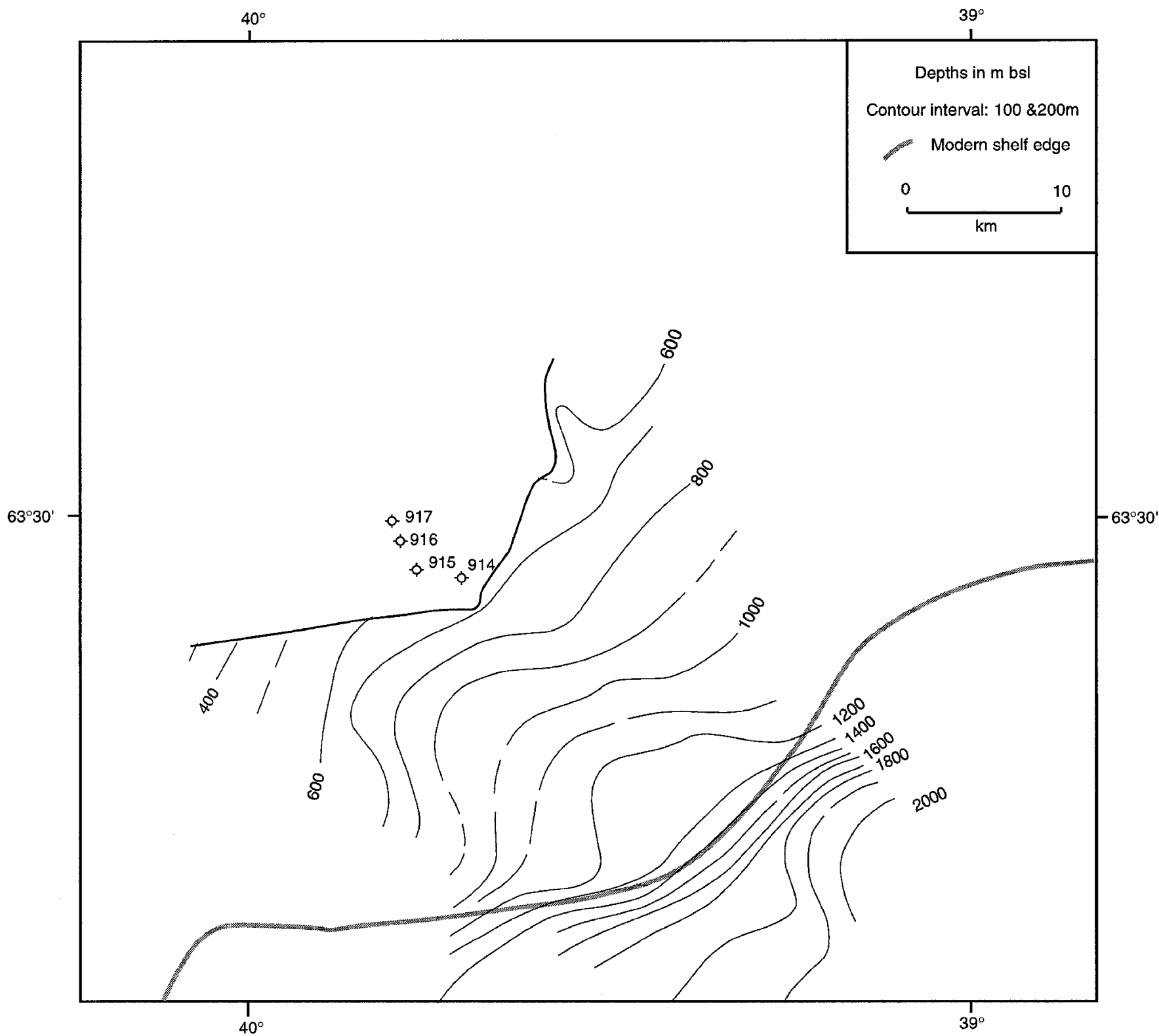

Figure 7. Structural contours for the base of Unit 2. Depths calculated by assuming $P$-wave velocities: water $1490 \mathrm{~m} / \mathrm{s}$ and sediments $1900 \mathrm{~m} / \mathrm{s}$.

shaped as a sheet pinching out toward the basement on the inner shelf and with abrupt terminations in a seaward direction (Figs. 2, 12). An isopach map describing the total thickness of Unit 1 (Fig. 10) shows a primary depocenter with thicknesses of up to $700 \mathrm{~m}$ at the modern shelf edge. A secondary depocenter with thicknesses reaching $250 \mathrm{~m}$ is located in the shelf trough about midway between the outcropping basement and the shelf edge.

The internal reflection patterns of the different segments of Unit 1 are sketched in Figure 2, and some details are shown in Figure 11. The trough fill shows a great variability of reflection characters. Domains with abundant continuous reflections interfinger with transparent domains or domains with hummocky to chaotic reflections with strongly varying amplitudes. Onlap is normally seen at the flanks of the shelf-trough. Internal unconformity surfaces are frequent, and internal reflections are truncated at the base of the covering Subunit 1A.

The approximately 50-m-thick sheet forming the connection between the trough fill and the slope fill (Fig. 2) is almost transparent, with few indistinct, subhorizontal internal reflections.
The slope fill is built of sigmoid clinoforms with abundant internal reflections. A few subunits may be discerned in the slope fill based on internal onlap surfaces in the shallow part. Three subunits were separated on profile EG92-24 (Fig. 2). The lower and the upper subunits correlate with the subhorizontal layers on the shelf. The intermediate subunit toplaps near the paleo-shelf edge. Irregular, upward-concave surfaces are seen to cut into the layers of the two upper subunits of the front-fill just below the shelf edge (Fig. 2). These features are interpreted as slide scars.

Subunit 1A, restricted to the trough, is almost transparent. Faint reflections are seen locally. A subhorizontal, mostly patchy reflection suggests that the subunit is a stack of two individual layers (Figs. 2, 11).

At Sites 914-917, a limited number of cores were recovered from levels corresponding to the seismic stratigraphic Unit 1 . The cores from Subunit 1A showed a succession composed of a surficial layer 2-15 m thick, consisting of glaciomarine mud with dropstones, underlain by a compacted diamicton with strong preferred orientation of 


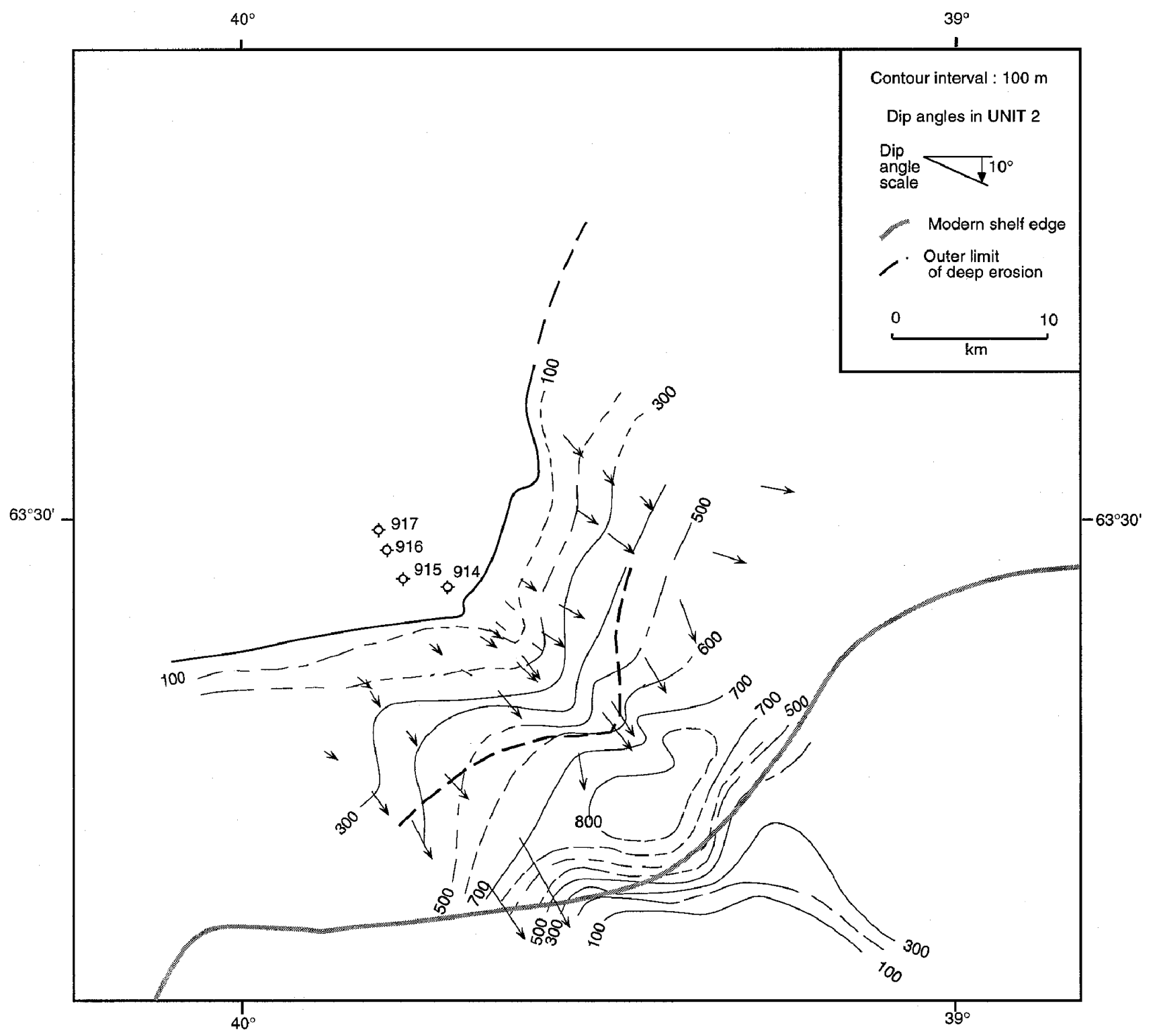

Figure 8. Isopachs for Unit 2 (late Miocene-Pliocene). Assumed $P$-wave velocity for the sediments: $1900 \mathrm{~m} / \mathrm{s}$.

microscopic grains characteristic for basal tills. Subunit 1B was represented by cores containing practically only coarse gravel with no matrix material recovered. The age of the recovered material was assumed to be Quaternary (Larsen, Saunders, Clift, et al., 1994). The stratigraphic position of Subunit 1B is further discussed below.

\section{SUMMARY AND DISCUSSION OF LATE CENOZOIC-QUATERNARY DEVELOPMENT OF SOUTHEAST GREENLAND SHELF}

The architecture of the late Cenozoic-Quaternary sedimentary sequence on the East Greenland shelf in the Gyldenløves Trough possesses the characteristics considered typical for sequences deposited by ice grounded on continental shelves in Antarctica (Cooper et al., 1991a) and Greenland (Larsen, 1994).

Based on the seismic data and the information from the drill sites on the southeast Greenland shelf, a model for the geological evolution since the onset of glaciations can be sketched.

In early late Miocene an increase of terrigenous detritus supplied by fluvial transport lead to the outbuilding of lobate deltaic deposits in the proximal parts of the shallow shelf sea. The increase in sediment influx is caused by intensified erosion exerted by growing glaciers on the Greenland continent.

In late late Miocene, glaciers reach the shoreline for the first time and periodically advance onto the shelf where the ice was grounded. Outside the grounding line at the paleo-shelf edge new material was supplied to the prograding slope. As suggested by the models described by Powell (1984), the sediments deposited on the slope most likely consist of diamictons produced by direct melt-out possibly with some stratification produced by fall-sorting, and layers of more well-sorted material deposited from melt water sediment plumes. Hambrey et al. (1991) found massive and stratified diamictons in a prograding sequence deposited near the grounding line on the shelf in Prydz Bay, Antarctica. In the drilled Prydz Bay prograding sequence, depositional slopes of about $4^{\circ}$ were associated with significant slumping (Hambrey et al., 1992). In contrast the southeast Greenland shelf maintains inclinations exceeding $10^{\circ}$ with only minor signs of slope collapse or slumping. Similar conditions were observed in a prograding sequence on the shelf off the Antarctic Peninsula (Hambrey et al., 1992). The large angles of stable slopes may indicate that these sequences consist of relatively coarse sediments possibly com- 


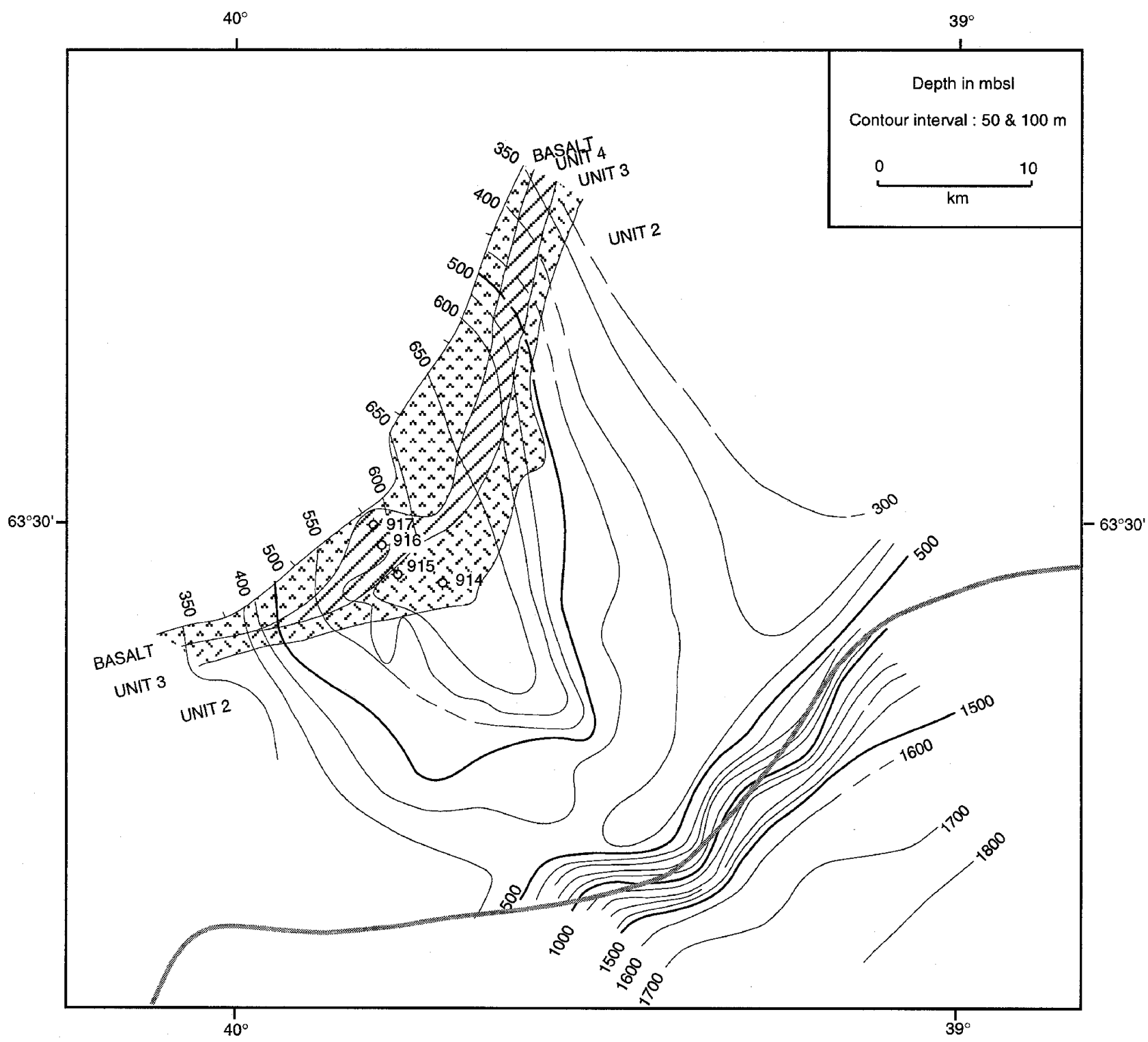

Figure 9. Structural contours and subcrop map for the base of Unit 1. Depths calculated by assuming $P$-wave velocities: water $1490 \mathrm{~m} / \mathrm{s}$ and sediments $1900 \mathrm{~m} / \mathrm{s}$.

posed of relatively angular particles as compared to the low-angle sequence drilled in Prydz Bay.

The depositional sequences delimited by the unconformities within the prograding clinoforms (Fig. 2) may indicate major glaciation periods separated by interglacials with reduced sediment supply to the shelf. Alternatively, the sequences are only of local significance, indicating temporal changes in the position of depositional lobes.

During periods of advance of the glacier ice across the shelf, parts of the previously deposited sediments were removed by basal erosion. By repeated advances to the steadily more remote shelf edge during the Pliocene, an erosional trough was created with the depth of erosion decreasing in a seaward direction (Fig. 2).

The erosional potential of the ice became reduced at some time represented by the deepest layers in Subunit 1B, and sediments deposited in the trough were not totally removed during the next advance. This new condition possibly reflected a rise in relative sea level and/or a decrease in thickness of the ice sheet.

For the relatively well-stratified but variegated trough fill (seismic stratigraphic Subunit 1B) two different depositional environments are envisaged: (1) a proglacial environment in front of a retreating ice and (2) a subglacial environment established below ice floating in the trough and grounded on the margins of the trough. In the proglacial environment the major volume of sediments is likely to come from glaciofluvial discharge producing subaqueous outwash fans and fine-grained deposits with ice-rafted debris (Elverhöi et al., 1983; Syvitski, 1989). As a minor constituent, melt-out tills and till tongues (King and Fader, 1986) at grounding lines along the trough margins are expected (Powell, 1984). In the subglacial environment fine-grained material deposited as well-stratified drape sheets may interfinger with till tongues at grounding line positions at the trough margins as demonstrated in the Emerald Basin on the Scotian shelf (Josenhans and Fader, 1989; Piper and Fader, 1990). The dominance of very coarse grained material recovered from the trough fill and the lack of pervasive well-stratified acoustic intervals favor the proglacial interpretation.

The major part of the trough fill (seismic stratigraphic Subunit 1B) onlaps the trough margins and is isolated from coeval events in the progradational sequence. If the proglacial interpretation is valid, the various subunits of the trough fill may correlate with unconformity surfaces in the progradational part of the shelf. Intervals for which the subglacial interpretation is valid may have coeval intervals in the progradational part of Subunit 1B. 


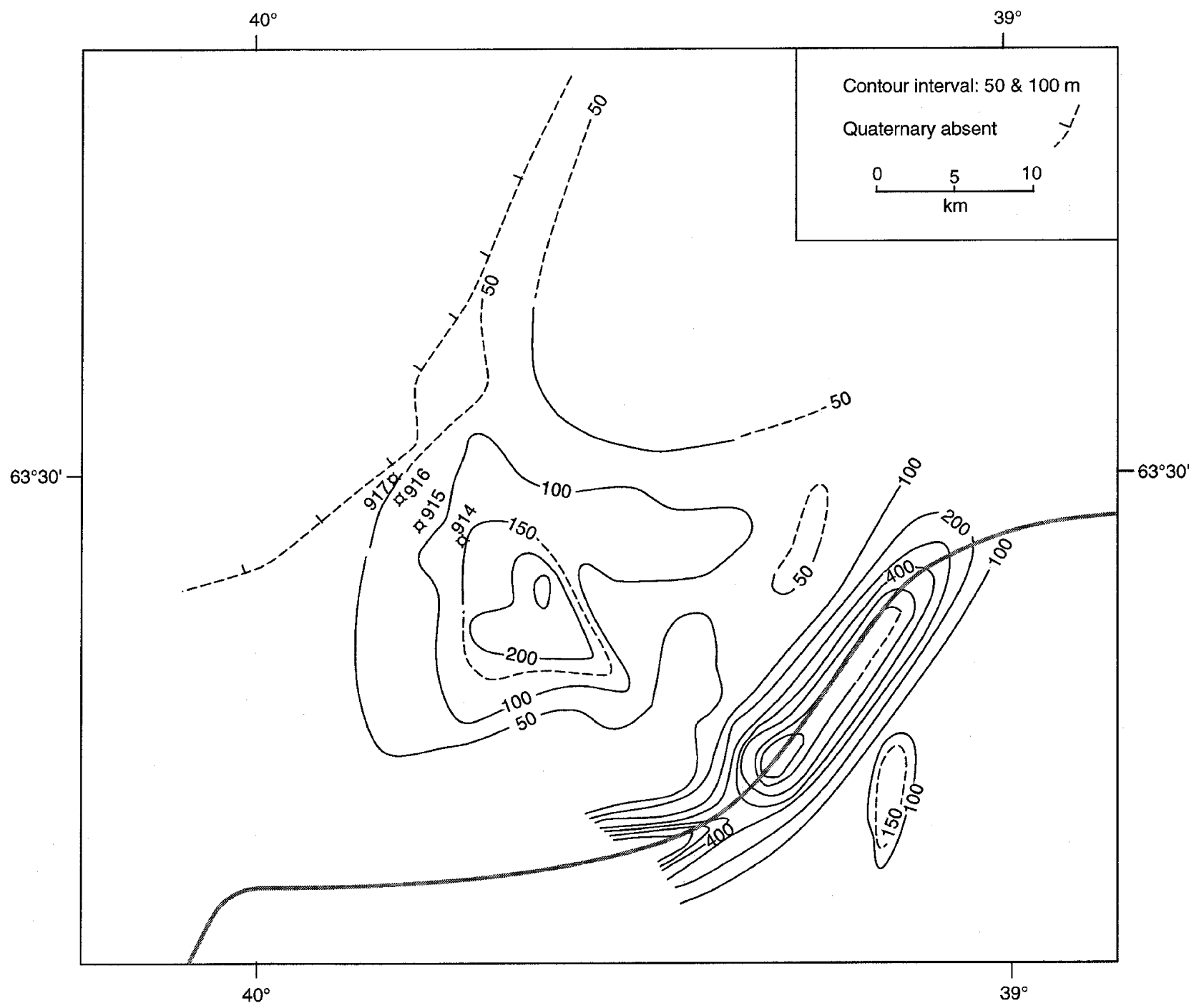

Figure 10. Isopachs for Unit 1. Assumed $P$-wave velocity for the sediments: $1900 \mathrm{~m} / \mathrm{s}$.

As no direct correlation between the onlapping trough fill and the prograding sequences is possible, the seismic data do not provide much constraint on the stratigraphic position of the trough fill. The fill may well be of Quaternary age as assumed by Larsen, Saunders, Clift, et al. (1994), but a Pliocene age of some of the (Subunit 1B) fill cannot be excluded.

After the time when the deeper parts of the erosional trough were practically filled (onlapping, lower parts of Subunit 1B), and the shelf topography correspondingly smoothed (Fig. 2), a series of new advances carried the ice to the shelf edge. These advances are the first from which the aggradational top layers (upper parts of Subunit 1B) have been preserved. These layers are interpreted as basal tills that grade into layers of glaciomarine diamictons deposited on the slope outside the grounding line. The uppermost part of the glaciomarine diamictons is visible, and clear indications of slope instabilities can be seen for the first time.

Investigations on the Jameson Land peninsula showed that the most extensive glaciations reaching onto the shelf in this area are of pre-Weichselian (presumably Saalian) age and that three Weichselian glacial advances developed only as topographically constrained valley glaciers (Funder et al., 1994). Assuming an analogue development in the Gyldenløves Trough about $700 \mathrm{~km}$ farther south, a preWeichselian age of the youngest sheet of till on the outer shelf and the correlative glaciomarine diamictons on the slope seems likely.
Later glacial advances to the shelf were restricted to glaciers in Gyldenløves Trough. The glaciers were grounded and basal tills deposited on the seaward side of the basement outcropping on the inner shelf. Two consecutive advances are documented by the seismic data, the younger one being slightly less extensive than the older (Fig. 12). It seems reasonable to assume that these late advances are coeval with the constrained advances of Weichselian age on the Jameson Land peninsula (Funder et al., 1994).

\section{ACKNOWLEDGMENTS}

The author wishes to thank Anders Solheim and Hans Christian Larsen for critical and constructive comments to the manuscript.

\section{REFERENCES}

Cooper, A., Barrett, P.J., Traube,V.V., and Stagg, H., 1991a. Cenozoic prograding sequences of the Antarctic continental margin: a record of glacio-eustatic and tectonic events. Mar. Geol., 102:175-213

Cooper, A., Stagg, H., and Geist, E., 1991b. Seismic stratigraphy and structure of Prydz Bay, Antarctica: implications from Leg 119 drilling. In Barron, J., Larsen, B., et al., Proc. ODP, Sci. Results, 119: College Station, TX (Ocean Drilling Program), 5-26. 
Elverhöi, A., Lønne, Ø., and Seland, R., 1983. Glaciomarine sedimentation in a modern fjord environment, Spitzbergen. Polar Res., 1:127-149.

Funder, S., Hjort, C., and Landvik, J.Y., 1994. The last glacial cycles in East Greenland, an overview. Boreas, 23:283-293.

Hambrey, M.J., Barett, P.J., Ehrmann, W.U., and Larsen, B., 1992. Cenozoic sedimentary processes on the Antarctic continental margin and the record from deep drilling. Z. Geomorph. N.F., 86:77-103.

Hambrey, M.J., Ehrmann, W.U., and Larsen, B., 1991. Cenozoic glacial record of the Prydz Bay continental shelf, East Antarctica. In Barron, J., Larsen, B., et al., Proc. ODP, Sci. Results, 119: College Station, TX (Ocean Drilling Program), 77-132.

Josenhans, H.W., and Fader, G.B.J., 1989. A comparison of models of glacial sedimentation along the eastern Canadian margin. Mar. Geol., 85:273300.

Kenney, C., 1984. Properties and behaviours of soils relevant to slope instability. In Brunsden, D., and Prior, D.B. (Eds.), Slope Instability: New York (Wiley), 27-65.

King, L.H., and Fader, G.B.J., 1986. Wisconsinan glaciation of the Atlantic Continental Shelf of southeast Canada. Geol. Surv. Can. Bull., 363

Larsen, B., 1994. Morphology and seismic stratigraphy of the East Greenland Shelf in the Denmark Strait Area compared to the Prydz Bay, Antarctica. Terra Antarct., 1:427-430.

Larsen, H.C., 1980. Geological perspectives of the East Greenland continental margin. Bull. Geol. Soc. Den., 29:77-101.

1990. The East Greenland Shelf. In Grantz, A., Johnson, G.L., and Sweeney, J.F. (Eds.), The Arctic Ocean Region. Geol. Soc. Am., Geol. of North Am. Ser., L:185-210.

Larsen, H.C., Saunders, A.D., Clift, P.D., et al., 1994. Proc. ODP, Init. Repts., 152: College Station, TX (Ocean Drilling Program).
Larsen, H.C., Saunders, A.D., Clift, P.D., Beget, J., Wei, W., Spezzaferri, S., and the ODP Leg 152 Scientific Party, 1994. Seven million years of glaciation in Greenland. Science, 264:952-955.

Mitchum, R.M., Jr., Vail, P.R., and Sangree, J.B., 1977. Seismic stratigraphy and global changes of sea level, Part 6. Stratigraphic interpretation of seismic reflection patterns in depositional sequences. In Payton, C.E. (Ed.), Seismic Stratigraphy: Applications to Hydrocarbon Exploration. AAPG Mem., 26:117-133.

Piper, D.J.W., and Fader, G.B., 1990. Quaternary geology: the southeast Canadian Region. In Keen, M.J., and Williams, G.L. (Eds.), Geology of the Continental Margin of Eastern Canada. Geol. Can., 2:506-526.

Powell, R.D., 1984. Glacimarine processes and inductive lithofacies modelling of ice shelf and tidewater glacier sediments based on Quaternary examples. Mar. Geol., 57:1-52.

Sommerhoff, G., 1979. Submarine glazial übertiefte Täler von Südgrönland. Eiszeitalter Ggw., 29:201-213.

Syvitski, J.P.R., 1989. On the deposition of sediment within glacier-influenced fjords: oceanographic controls. Mar. Geol., 85:301-329.

Vorren, T.O., Lebesbye, E., Andreassen, K., and Larsen, K.B., 1989. Glacigenic sediments on a passive continental margin as exemplified by the Barents Sea. Mar. Geol., 85:251-272.

Date of initial receipt: 27 November 1995

Date of acceptance: 29 July 1996

Ms 152SR-209

$92-24$
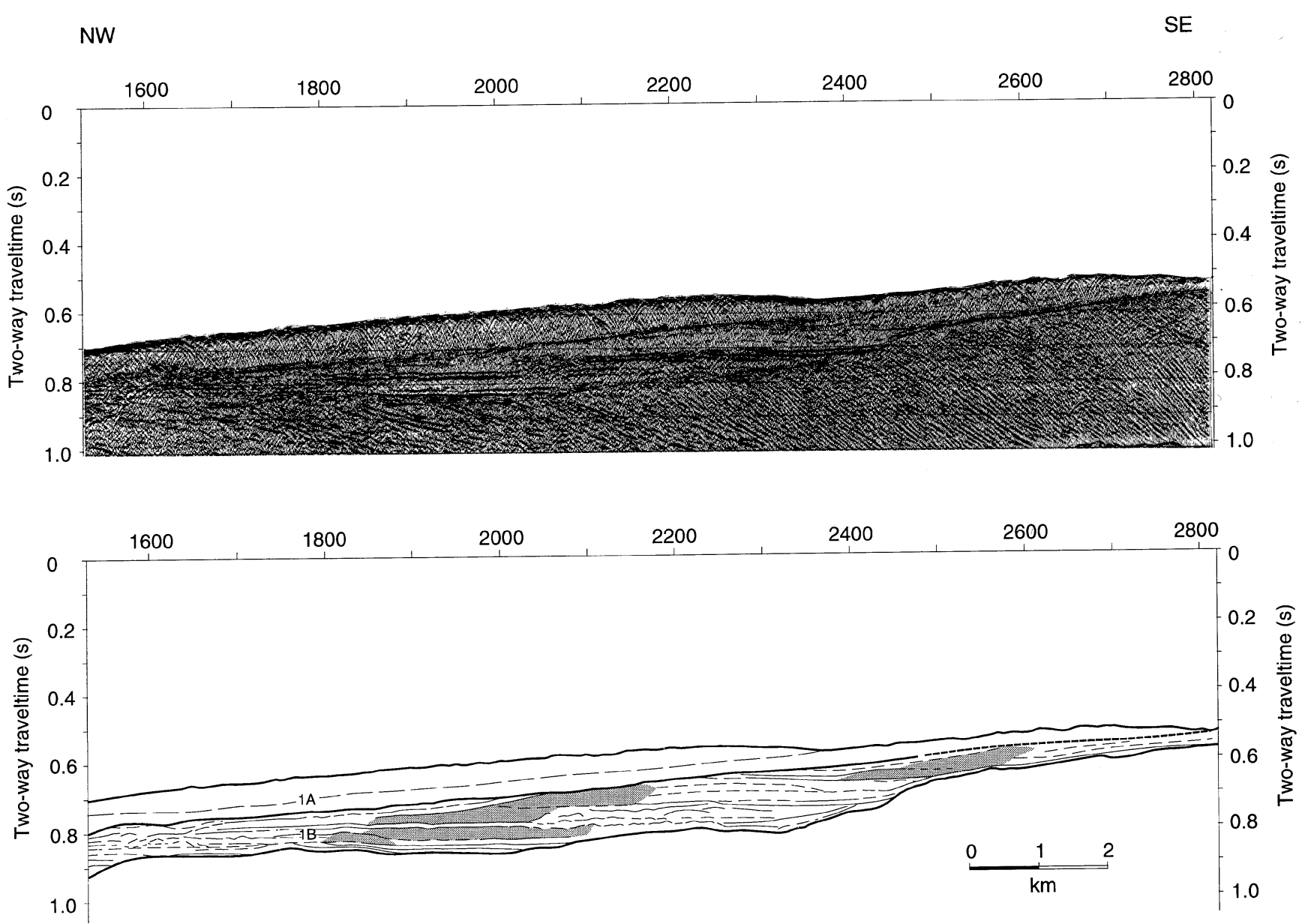

Figure 11. Part of EG92-24 showing the architecture of Unit 1 in Gyldenløves Trough. Hatched areas indicate possible till tongues. See Figure 2 for location. 


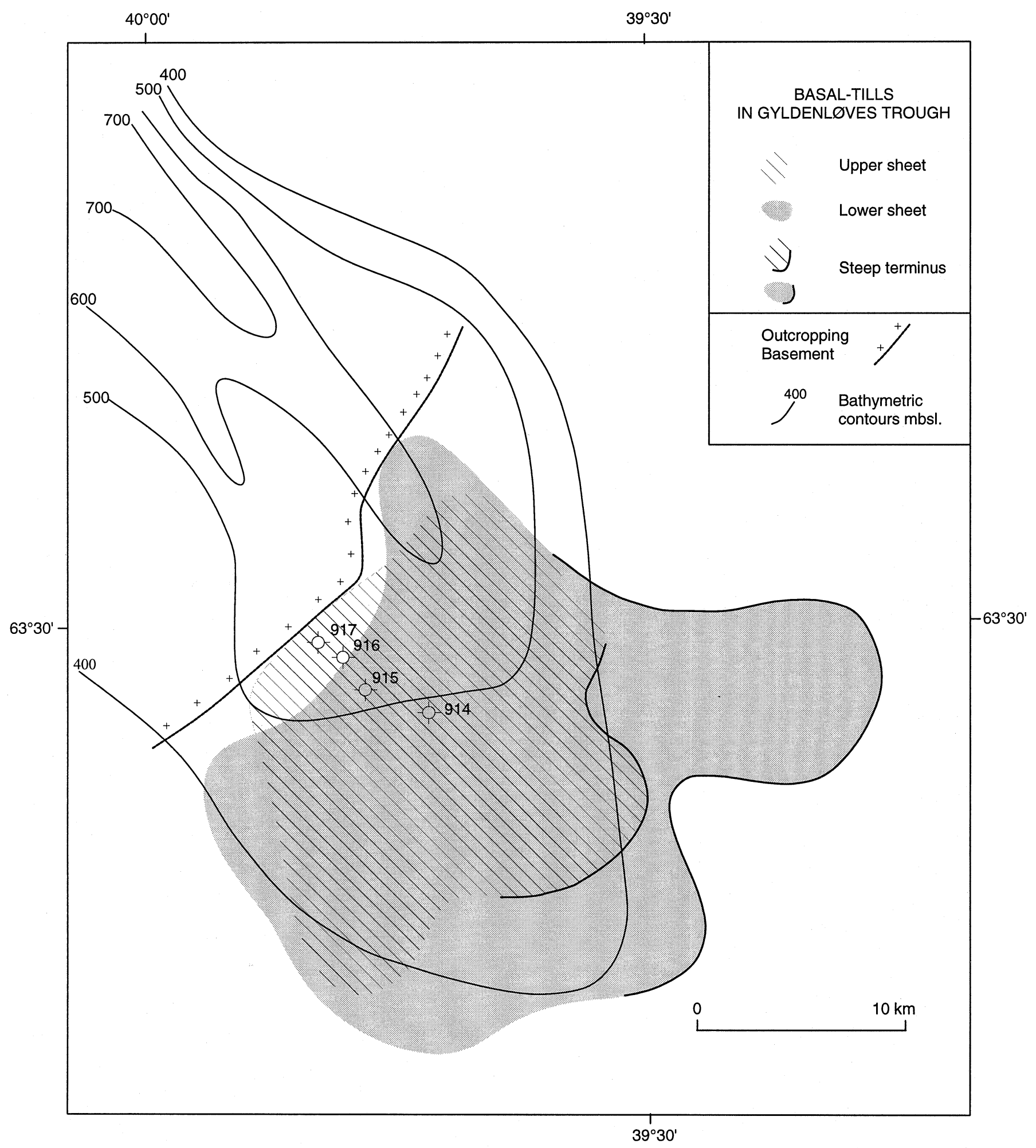

Figure 12. Map showing the extent of the latest (assumed Weichselian) glaciations reaching the shelf in Gyldenløves Trough. 